Original Article

Received/Accepted

Dates

29.05.2021/25.06.2021

DOI

10.52096/jsrbs.6.1.7.13.14
Journal of Social Research and Behavioral Sciences

Sosyal Araştırmalar ve Davranış Bilimleri Dergisi

ISSN:2149-178X

Volume: 7 Issue: 13 Year: 2021

\title{
Sosyal Yardımlaşma ve Dayanışma Vakıflarından Sosyal Yardım Alan Kadınların Bazı Sosyo-Demografik Özellikleri ile Yoksullukla Bağlantılı Deneyim ve Görüşleri ${ }^{1}$
}

Dr. Melike YALÇIN

melikeyalcin84@gmail.com

ORCID ID: 0000-0002-2312-276X

\section{Özet}

$\mathrm{Bu}$ araştırma ile sosyal yardımlaşma ve dayanışma vakıflarından sosyal yardım alan yoksul kadınların bazı sosyo-demografik özellikleri, yoksullukla bağlantılı deneyim ve görüşleri ile yoksullukla baş etme ve güç durumlarının ortaya çıkarılması amaçlanmıştır. Araştırmada nicel araştırma yöntemi kullanılmış olup, veriler Ankara ili Altındağ, Mamak ve Keçiören İlçe Sosyal Yardımlaşma ve Dayanışma Vakıflarından sosyal yardım alan ve araştırmaya katılmayı kabul eden kadınlar ile Görüşme Formu kullanılarak yüz yüze görüşme yapılarak elde edilmiştir.

Araştırmaya katılan yoksul kadınlar, genç yetişkin dönemde, eğitim düzeyi düşük, evli ve en az bir çocuk sahibi, çalışmayan ve geçimini sosyal yardımlarla sağlayan kadınlardır. Yoksulluğu ihtiyaçlarını karşılayamamak olarak tanımlamakta ve yoksulluğun nedenini işsizlik olarak belirtmektedirler. Katılımcılar sosyal yardımları yoksullukla baş etme stratejisi olarak görmekte olup, verilen yardımların geçimlerini sağlamaya yetmediğini düşünmektedirler. Kadınların yoksulluktan erkeklere göre daha çok etkilendiğini düşünmekte, güçlü yanlarını ise en çok iyi bir anne ve eş olma üzerinden tanımlamaktadırlar. Anahtar Kelimeler: Sosyal Yardımlar, Kadın Yoksulluğu, Sosyal Hizmet

Jel Kodu: I39

\footnotetext{
${ }^{1} \mathrm{Bu}$ çalışmada yazarın doktora tezindeki verilerin bir kısmı kullanmıştır. Bu çalışma 25-27 Haziran 2021 tarihleri arasında düzenlenen SADAB 9. Uluslararası Sosyal Araştırmalar ve Davranış Bilimleri Sempozyumunda sözel bildiri olarak sunulmuştur.
} 


\title{
Some Socio-Demographic Characteristics of Women Receiving Social Assistance from Social Assistance and Solidarity Foundations, and Experiences and Views Related to Poverty
}

\begin{abstract}
With this research, it is aimed to reveal some socio-demographic characteristics, experiences and opinions related to poverty, and power situations of coping with poverty of poor women who receive social assistance from social assistance and solidarity foundations. The quantitative research method was used in the study, and the data were obtained by making face-to-face interviews with women who received social assistance from Ankara province Altındağ, Mamak and Keçiören Social Assistance and Solidarity Foundations and accepted to participate in the study.

The poor women participating in the research are young adult women with a low level of education, married, have at least one child, are unemployed and earn their living on social assistance. They define poverty as not being able to meet their needs and state the reason for poverty as unemployment. Participants see social assistance as a strategy to cope with poverty and think that the aid given is not enough to provide for their livelihood. They think that women are affected more by poverty than men, and they define their strengths mostly as being a good mother and wife.
\end{abstract}

Keywords: Social Assistance, Women Poverty, Social Work

\section{Giriş}

Yoksulluk ekonomik, toplumsal, bireysel pek çok nedene dayanan ve bu nedenle tek bir tanıma indirgenemeyen küresel bir sorundur.

Kadınlar, toplumsal cinsiyet eşitsizliklerinden kaynaklanan pek çok nedene dayalı olarak hem kadın hem de yoksul olmanın dezavantajını birlikte yaşamaktadırlar (Ecevit, 2003; Ünlütürk Ulutaş, 2009; East ve Roll, 2015).

"Kadın yoksulluğu temel olarak, - yoksul kadın oranının yoksul erkek oranından daha fazla olması - kadınların yoksulluğu erkeklerden daha şiddetli yaşamaları ve - kadın hane halkı reislerinin sayısının artması" ile açıklanmaktadır (Kardam ve Yüksel, 2004, s.46).

Kadınlar, kültürel normlar ve değerler, mal ve varlıklara ilişkin dağılımdaki eşitsizlikler, erkekler ile aralarındaki eşitsiz güç dinamikleri nedeniyle yoksulların çoğunluğunu oluşturmaktadır. Ek olarak, yoksulluğa yönelik politikalar, erkeklerin hanenin geçimini sağlayan ve kadınların erkeğe 
bağımlı olduğu bakış açısıyla ele alınmaktadır. Yoksulların büyük bir çoğunluğunu kadınlar oluşturmaktadır ve genellikle yoksulların en yoksuludurlar. Kadın olmaları nedeniyle karşılaştıkları toplumsal dezavantaj ve eşitsizlik, kadınların yoksulluk deneyimlerini erkeklere göre farklılaştırmakta, kırılganlıklarını artırmakta ve yoksulluktan kurtulmalarını zorlaştırmaktadır. Başka bir deyişle yoksulluk, toplumsal cinsiyete dayalı bir deneyim olarak varlığını sürdürmektedir. Kadın yoksulluğu, toplumdaki normların ve değerlerin, mal ve varlıkların, hane içindeki iş ve sorumluluğun bölüşümünün ve yoksul hanelerde kadın ve erkek arasındaki güç ve kontrol dinamiklerinin toplumsal cinsiyet analizini gerektirmektedir. Kadın ve erkek rollerindeki cinsiyet eşitsizliği ve farklılıkları kadın yoksulluğunun nedenlerini, deneyimlerini ve sonuçlarını büyük ölçüde etkilemektedir (Tarkowska, 2002; Rao Gupta, 2012, s.12).

Yoksullukla mücadelede önemli bir araç olan sosyal yardımlar ise temel ihtiyaçlarını karşılamakta zorluk yaşayan bireylere yönelik bir sosyal güvenlik yöntemi ve aynı zamanda bir sosyal hizmet alanıdır. Daha kapsamlı tanım ise Karataş tarafından "Yerel ölçüler içinde asgari seviyede dahi kendisini ve bakmakla yükümlü olduğu kişileri geçindirme olană̆ından kendi ellerinde olmayan nedenlerden dolayı yoksun kalmış kişilere resmi kuruluşlar veya kanunların verdiği yetkiye dayanarak yarı resmi veya gönüllü kuruluşlarca muhtaçlık tespitine ve kontrolüne dayalı olarak yapılan ve kişileri en kısa sürede kendi kendilerine yeterli hale getirmek amacını taşıyan parasal ve nesnel sosyal gelirden oluşan bir sosyal güvenlik yöntemi ve bir sosyal hizmet alanıdır" olarak yapılmaktadır (2002;131). Sosyal yardımlar, yoksullukla mücadelede süreklilik arz etmeyen, geçici ve temel ihtiyaçların karşılanmasına yönelik bir araç olarak da ifade edilebilir.

$\mathrm{Bu}$ araştırmada kamu tarafından sunulan sosyal yardım hizmetlerinden yararlanan yoksul kadınlara yönelik elde edilen veriler çerçevesinde, kadın yoksulluğunu görünür kılmak ve politika yapıcılara sonuçlara bağlı olarak yol göstermek amaçlanmıştır.

\section{Yöntem}

\subsection{Araştırmanın Modeli ve Amacı}

Araştırma nicel araştırma yöntemi genel tarama modellerinden tekil tarama modeli kesit alma yaklaşımı kullanılarak oluşturulmuştur. Mart 2019-Mayıs 2019 zaman aralığında gerçekleştirilen 
söz konusu araştırmada kesit alma yaklaşımının kullanılmasının nedeni araştırmacıya zaman ve maliyet açısından tasarruf sağlamaktır.

Bununla birlikte araştırmanın temel amacı, yoksul kadınların sosyo-demografik ve sosyoekonomik özellikleri, yoksullukla bağlantılı deneyim ve görüşleri ile yoksullukla baş etme biçimleri, güçlü ve güçsüz yanlarının ortaya konulmasıdır.

\subsection{Araştırma Grubu}

Çalışmanın evreni, sosyal yardımlaşma ve dayanışma vakıflarından (SYDV) sosyal yardım alan yoksul kadınlardır. Araştırmanın örneklemini ise Mart 2019-Mayıs 2019 tarihleri arasında SYDV'lerden yardım alan çocuklu ya da çocuksuz, 18 yaş ve üzerinde, araştırmaya katılmayı kabul eden 150 kadın oluşturmaktadır.

\subsection{Veri Toplama Araçları}

Araştırmanın verileri literatür bilgilerine dayalı olarak araştırmacı tarafindan oluşturulan ve "Görüşme Formu" aracıllğı ile elde edilmiştir.

2.3.1. Görüşme Formu: Görüşme formunda yoksul kadınların sosyo-demografik özellikleri (yaş, doğum yeri, eğitim durumu, medeni durum, evlenme şekli, ilk evlilik yaşı, çocuk sahibi olma durumu ve sahip olunan çocuk sayısı); sosyo-ekonomik özellikleri (halihazırda çalışma durumu ve halihazırda çalışmayanların çalışmama nedeni, çalışmak için başvuru durumu, halihazırda çalışanların yaptığı iş, yaptığ iş̧en yeterli kazanç sağlama durumu, düzenli gelir durumu, geçim kaynakları, Vakıftan alınan sosyal yardım türü ve yardımın geçimini sağlama durumu, ikametin mülkiyet durumu, borç durumu); yoksul kadınların yoksulluğu deneyimleme biçimleri (yoksulluğu nasıl tanımladığı, yoksulluğun nedeni, yoksulluk nedeniyle en çok hangi duyguyu hissettikleri, yoksulluk nedeniyle yaşadıkları en önemli sorun, kadınların yoksulluktan erkeklere göre daha çok etkilenme durumu ve bunun nedeni); yoksul kadınların yoksullukla baş etme stratejileri ve güç durumları (yoksullukla baş etme yöntemleri, sorunlarının üstesinden gelmek için kendini yeterince güçlü hissedip hissetmediği, güçlü yanları, yaşamını değiştirme yönünde bugüne 
kadar yaptıkları, geleceğine yönelik değerlendirmeleri, yoksulluğun çözümüne yönelik beklentileri) yönelik sorular bulunmaktadır.

\subsection{Veri Toplama Süreci}

Araştırmanın gerçekleştirilmesi için 19.02.2019 tarihinde Hacettepe Üniversitesi Etik Komisyonundan, Keçiören SYDV'den 28.03.2019 tarihinde, Mamak SYDV'den 20.03.2019 tarihinde ve Altındağ SYDV'den 28.03.2019 tarihinde izin alınmıştır. İzinlerin sonrasında her bir SYDV'de Mart 2019 - Mayıs 2019 tarihleri arasında gönüllülük esasına göre belirlenen katılımcılardan yazılı bilgilendirilmiş onam alınarak veriler elde edilmiştir.

\subsection{Verilerin Analizi}

Bu araştırmanın verileri, SPSS Paket Programı 22 ile çözümlenmiştir. Söz konusu çözümlemede basit ve çapraz tablolar kullanılmıştır. Sıklık analizleri yüzdelik olarak yer almıştır.

\subsection{Araştırmanın Sınırlııkları}

Araştırmanın örneklemi SYDV'lerin sosyal yardım hizmetlerinden yararlanan ve araştırmaya katılmayı kabul eden katılımcılar ile sınırlandırılmıştır. Bununla birlikte veri toplama süresi Mart 2019- Mayıs 2019 tarihleri ile sınırlandırılmıştır. Söz konusu sınırlamalar araştırmacının kısıtlı zamanı olması sebebiyle belirlenmiştir.

\section{Bulgular}

$\mathrm{Bu}$ çalışmada araştırmanın bulguları yoksul kadınların sosyo-demografik bilgileri, sosyoekonomik özellikleri, yoksulluğu deneyimleme biçimleri, yoksullukla baş etme stratejileri ile güç durumları çerçevesinde açıklanmaktadır. 
Tablo 1. Sosyo-Demografik Bilgiler

\begin{tabular}{|c|c|c|}
\hline Yaş & Sayı & Yüzde \\
\hline $28-37$ & 52 & 34,7 \\
\hline $38-47$ & 44 & 29,3 \\
\hline $18-27$ & 28 & 18,7 \\
\hline $48-57$ & 18 & 12 \\
\hline 57 ve üstü & 8 & 5,3 \\
\hline \multicolumn{3}{|l|}{ Doğum Yeri } \\
\hline İl & 63 & 42 \\
\hline Koy & 43 & 28,7 \\
\hline İlçe & 42 & 28 \\
\hline Kasaba & 2 & 1,3 \\
\hline \multicolumn{3}{|l|}{ Eğitim Durumu } \\
\hline İlkokul & 73 & 48,7 \\
\hline Ortaokul & 33 & 22 \\
\hline Okur-yazar Değil & 23 & 15,3 \\
\hline Lise & 15 & 10 \\
\hline Üniversite & 6 & 4 \\
\hline \multicolumn{3}{|l|}{ Medeni Durum } \\
\hline Evli & 108 & 72 \\
\hline Eşi Vefat Etmiş & 31 & 20,7 \\
\hline Bekar & 8 & 5,3 \\
\hline İmam Nikahlı Beraberlik & 3 & 2 \\
\hline \multicolumn{3}{|l|}{ Evlenme Şekli } \\
\hline Görücü Usulü & 88 & 62 \\
\hline Anlaşarak & 48 & 33,8 \\
\hline Diğer (Kaçarak) & 6 & 4,02 \\
\hline \multicolumn{3}{|l|}{ İlk Evlilik Yaşı } \\
\hline $16-20$ & 87 & 61,2 \\
\hline $21-35$ & 29 & 20,4 \\
\hline
\end{tabular}


15 yaş ve altı $\quad 24 \quad 16,9$

35 yaş ve üstü $2 \quad 1,4$

Çocuk Sahibi Olma

\section{Durumu}

Var 133

92,3

Yok

\section{Sahip Olunan Çocuk Sayısı}

3

2

4 ve yukarısı

1

\section{5}

30

24

11

Katılımcılar 28-37 yaş $(\% 34,7)$ arasında genç yaş grubu kadınlardan oluşmakta olup, en çok bir İlde (\%42) doğmuştur. Kadınların eğitim durumlarına ilişkin veriler incelendiğinde ise en çok ilkokul mezunu $(\% 48,7)$ oldukları görülmektedir. Bunu ortaokul (\%22) ve okur-yazarlığ bulunmayanlar $(\% 15,3)$ izlemektedir. Nitekim sosyal yardım alan kadınlarla gerçekleştirilen başka araştırmaların sonuçlarında da kadınların en çok ilkokul mezunu oldukları saptanmıştır (Aca, Özdemir ve Alper, 2018; Ekinci Hamamcı ve Anık, 2020). Eğitimli olmaları sayesinde kadınlar daha rahat bağımsız bir yaşam kurabilir, bilgi ve beceri sahibi olabilir. Böylece kadınların özgüveni artarak, sorun çözme kapasitesi gelişir. Başka bir değişle eğitim, kadınların güçlenmelerinde önem teşkil eden değişkenlerden biridir. Ülkemizde 25 yaş ve üzeri ilkokul mezunu nüfus oranı kadınlarda $\% 6,9$, erkeklerde $\% 1,2$; ortaokul mezunu kadın $\% 10,7$, erkeklerde $\% 14,3$; lise mezunu kadınlarda $\% 17,5$, erkeklerde $\% 25,4$; yüksekokul veya fakülteden mezun nüfus oranı kadınlarda $\% 16,3$; erkeklerde $\% 20,1$; okur-yazar olmayan kadınlarda $\% 6,9$, erkeklerde \%1,2'dir (TÜİK, 2021). Kadınların eğitim durumuna göre yoksulluk oranları incelediğinde ise okur-yazar olmayanların \%35'i; bir okulu bitirmeyenlerin \%29,8'i; lise altı eğitimlilerin \%18,4'ü; lise ve dengi okul mezunların \%10,3'ü; yükseköğretim mezunlarının ise \%3,7 yoksuldur (TÜiK, 2020). Bu verilerden de anlaşılacağı üzere, kadınlarda eğitim düzeyi arttıkça, yoksulluk oranı azalmaktadır. 
Katılımcıların medeni durumları incelendiğinde ise \%72'sinin evli olduğu, \%20,7'inin eşinin vefat ettiği görülmekte olup, büyük bir kısmı (\%62) evliliklerini görücü usulü ile gerçekleştirmiştir. Katılımcıların yarısından fazlası $(\% 61,2)$ ilk evliliğini 16-20 yaş arasında gerçekleştirmiştir. Bununla birlikte, 15 yaş ve altında $(\% 16,9)$ evlilik gerçekleştirenlerde bulunmaktadır. Erken yaşta evlenen kadınların büyük çoğunluğu eğitime devam edememekte, bunun bir sonucu olarak çalışamamakta ve eşinin gelirine bağımlı hale gelebilmektedir. Otoo-Oyortey ve Pobi'ye göre (2003) erken yaşta evlilikler, okul dönemindeki kız çocuklarının evlenmesi ve bu nedenle eğitim hayatının sonlanması nedeniyle düşük eğitim düzeyi ile doğrudan bağlantılı bir konudur. Ayrıca, olumsuz sağlık durumu, düşük özsaygı ve sosyal izolasyonla da ilişkilendirilmektedir. Bu nedenle erken yaşta evlilikler kız çocuklarının gelecekteki haklarının ihlal edilmesi ve kadın yoksulluğunun sürdürülmesiyle yakından ilgilidir. Çamur Duyan'ın (2010) Ankara ili Altındağ bölgesinde yaşayan yoksul kadınlarla gerçekleştirdiği bir araştırmanın sonuçlarında göre de katılımcılar düşük eğitim seviyesine sahip, göç geçmişi bulunan, erken yaşta evlilik gerçekleştiren kadınlardan oluşmaktadır. Nitekim söz konusu araştırmanın sonuçları da bu araştırmanın sonuçları ile benzerlik taşımaktadır. Katılımcıların tamamına yakınının (\%92,3) çocuğu bulunmakta olup, çocuğu bulunanların en çok üç çocuğu (\%35) vardır. Çok çocuklu olmanın yoksulluk riskini arttıran bir değişken olduğu, özellikle iki yetişkin ve üç çocuklu ailelerde bu riskin daha yüksek olduğu belirtilmektedir (Buğra ve Keyder, 2007, s.11).

Tablo 2. Sosyo-Ekonomik Özellikler

\section{Hali Hazırda Çalışma}

Durumu

Sayı Yüzde

$\begin{array}{lcc}\text { Çalışmayan } & 119 & 79,3 \\ \text { Çalışan } & 28 & 19,3\end{array}$

\section{Hali Hazırda Çalışmama}

\section{Nedeni}

Çocuğumun Bakımı

Nedeniyle

Diğer

Eşin İzin Vermemesi 
Yeterli Eğitimi Yok

14

Yaşı Çalışmaya Uygun Değil

Yaşl1/Engelli Bireye Bakma

Nedeniyle

\section{Çalışmak İçin Başvuru}

\section{Durumu}

Hayır

103

16

Evet

\section{Hali Hazırda Yaptığı İş}

Temizlik/Bulaşık vb. işler

Çocuk/engelli/yaşlı

bakımı

Parçabaşı İş

Diğer

Yaptığı İșten Yeterli

Kazanç Sağlama

Hayır

89,2

Kismen

\section{Düzenli Gelir Durumu}

Yok

105

45

Var

\section{Geçim Kaynakları}

Devletten Aldığı Yardımlar

Diğer

Çalışarak

Çevre Desteği

\section{Vakıftan Alınan Sosyal}

Yardım Türü

Aile Yardımı

84

11,7

6,7

5

86,5

13,5

42,8

32,1

14,2

10,7

Eğitim Yardımı

Özel Amaçlı Yardım
34

30

18,7

11,3 56

39,3

14,7 
Yaşlı ve Engelli Yardımı

Sağlık Yardımı

\section{Vakfın Geçimi Sağlama}

\section{Durumu}

Hayır

Evet

K1smen

Evin Mülkiyet Durumu

Kira

Diğer

Kendine Ait

Borç

Var

Yok
18

14

12

9,3

91

11

48

7,3

32

77

51,3

32

21,3

7

4,7

87

63
58

42

Araştırmaya katılan yoksul kadınların büyük bir bölümü $(\% 79,3)$ herhangi bir işte çalışmamaktadır. Çalışmama nedeni olarak ise en çok çocuklarının bakım ihtiyacını (\%31) belirtmişlerdir. Bunu "Diğer" $(\% 28,5)$ olarak ifade edilen "Eğitime devam etme, kendine güveninin olmaması, hastalık, hasta eşe bakma zorunluluğu, iş arama, ücret tatminsizliği, iş bulamama, engel ya da hastalık durumu" izlemektedir. Yoksul hanelerde kadının çalışıyor olması, ailenin gelirine katkı sağlaması açısından önemlidir. Bununla birlikte özellikle geleneksel yapıdaki ailelerde kadının çalışması sıklıkla eşin ya da babanın izni ile mümkün olmaktadır (Kalaycıŏglu ve Rittersberger-Tılıç, 2002). Sosyal yardım alan yoksul kadınlarla gerçekleştirilen başka bir çalışmada da kadınlar çalışmama nedenlerini en çok çocuk bakımı, eşin izin vermemesi ve ev işleri nedeni olarak açıklamışlardır (Alptekin ve Aksan, 2010). Katılımcılardan herhangi bir işte çalışmayanlar için başvuru durumuna yönelik dağılım incelendiğinde ise \%86,5'inin başvuruda bulunmadığı tespit edilmiştir. Hâlihazırda bir işte çalışan kadınlar en çok temizlik/bulaşık (\%42,8), çocuk/engelli/yaşlı bakımı (\%32,1) ya da parça başı iş (\%14,2) gibi daha çok kayıt dişı ve enformel sektörlerde, kadınlık rolleri açısından kendileri için "uygun görülen" işlerde çalışmaktadırlar. Yoksul kadınlarla gerçekleştirilen başka bir araştırmada da katılımcıların en çok çocuk bakımı, temizlik gibi enformel işlerde çalıştıklarını ifade ettikleri görülmektedir (Ekinci Hamamcı ve Anık, 
2020). Kayıt dışı işler ile yoksulluk arasında ilişki bulunmakta olup, kayıt dışı istihdam arttıkça kadın yoksulluğu artmakta, yoksulluk arttıkça kadınlar söz konusu işlerde çalışmayı kabul etmektedir (Şener, 2009).

Çalışıyor olmak yoksul olmamak anlamına gelmemektedir. Nitekim çalışanlar arasında da yoksul olanlar bulunmaktadır. Bu nedenle yoksulluk politikalarında işsizlikle mücadelenin önemli bir bileşenini de sürdürülebilir işlerin oluşturması gerektiği vurgulanmaktadır (Buğra ve Keyder, 2007). Günümüzde "yoksulluğun artık geçici, işsizliğe bağll, istisnai değil, tersine kuşaklar arasında aktarılan, kalıcı ve yapısal bir gerçeklik olduğu ve ekonomik büyüme ve istihdam artışını sağlama gibi “çözüm”lerin, yoksulluğu hafifletmekte etkili olamadığı belirtilmektedir" (Bora, 2007; aktaran Şener, 2009, s.3). Kadınların istihdama katılmaları ve düzenli gelir elde etmeleri, hem güçlenmeleri hem de aile ve eşe bağımlı olmalarını önleyen en önemli değişkenlerdendir. Bununla birlikte, özellikle eğitim düzeyi düşük, yoksul ailelerden gelen ve çalışmak için gereken nitelikleri sağlayamayan kadınların düzenli ve gelir getirici işlerde yer almaları daha zor olmaktadır. Nitekim katılımcılardan düzenli gelirinin bulunup bulunmadığına yönelik soruya \%70'i "Hayır" yanıtını vermiştir. Kadınların geçim kaynaklarının neler olduğuna yönelik dağılımda ise en çok devletten aldıkları yardımlarla geçimlerini sağladıkları (\%34) görülmektedir. Bunu "Diğer" (\%30) olarak ifade edilen "Eşe bağımlılık, nafaka, çocuğunun maaşı, kâğıt ya da plastik toplayıcılığı" izlemektedir. Bu verilerden de anlaşılacağı üzere sunulan sosyal yardımlar, geliri bulunmayan ya da var olan geliri yeterli olmayan yoksul kadınlar için bir geçim aracına dönüşmüş durumdadır. Oysaki sosyal hizmet bakış açısıyla sosyal yardımların temel amacının hak temelli yaklaşım kapsamında bireylerin kendilerine yeterli hale gelebilecekleri duruma kadar sunulan bir sosyal destek mekanizması olması beklenir. Bununla birlikte sosyal yardımların yoksul bireylerin geleceğine yönelik kendilerini daha az kaygılı hissetmeleri ve daha istikrarlı bir yaşam sürmelerinde önemli olduğundan bahsedilmektedir (Buğra ve Keyder, 2002).

Katılımcıların SYDV'lerden aldıkları yardım türleri incelendiğinde ise en çok aile yardımı kapsamındaki doğum yardımı, eşi vefat etmiş kadınlara yönelik düzenli nakit yardım programı, öksüz ve yetim yardımlarını aldıkları görülmektedir. Bunu, eğitim yardımları kapsamındaki şartlı eğitim yardımları, eğitim materyali yardımı gibi yardımlar izlemektedir. Söz konusu yardımların geçimlerini sağlayıp sağlamadığına ilişkin değerlendirmede ise, katılımcıların büyük çoğunluğu $(\% 60,7)$ geçimini sağlamaya yetmediğini ifade etmiştir. Sosyal yardımların yoksul bireyler 
üzerindeki etkisine yönelik gerçekleştirilen başka bir araştırmanın sonuçlarına göre de söz konusu yardımların her ne kadar yoksullar üzerinde bağımlılık oluşturan bir etkisi olsa da yoksulluğun olumsuz sonuçlarıyla mücadelede etkili olduğu aktarılmıştır (Apaydın, 2011). Bu noktada her ne kadar söz konusu yardımlar, yoksul kadınların geçimini sağlamak için yeterli olmasada, yoksullukla baş etme stratejilerinden biri olarak görülmektedir.

Kadınların ikamet ettikleri konutun mülkiyet durumu incelendiğinde ise büyük bir çoğunluğunun $(\% 51,3)$ kirada oturduğu, bunu Diğer $(\% 21,3)$ olarak belirtilen "Eşinin ailesi ya da kendi ailesine ait bir evde ya da tapusuz bir ev" seçeneği izlemektedir. Katılımcıların yalnızca \%4,7'si mülkiyeti kendisine ait bir evde oturduğunu belirtmiştir. Katılımcıların borçlarının bulunma durumuna ilişkin soruya büyük çoğunluğu (\%58) borcunun bulunduğu şeklinde yanıt vermiştir. Nitekim borç almak, yeterli gelire sahip olmayan yoksul bireyler için yoksullukla baş etmenin başka bir yoludur.

Tablo 3. Yoksul Kadınların Yoksulluğu Deneyimleme Biçimleri

\begin{tabular}{lcc}
\hline Yoksulluğu Tanımlama & Sayı & Yüzde \\
Biçimi & 95 & 63,3 \\
\hline İhtiyacını Karşılayamamak & 25 & 16,8 \\
Başkasına Muhtaç Olmak & 14 & 9,3 \\
Geçinememek & 10 & 6,6 \\
Diğer & 6 & 4 \\
Çocuğunun İsteklerini & & \\
Karşılayamamak & & \\
Genel Olarak Yoksulluğun & & \\
Nedenlerine İlişkin & & \\
Görüşleri & 117 & 78 \\
İşsizlik & 82 & 54,7 \\
Toplumdaki Eşitsizlik & 59 & 39,3 \\
Eğitimsizlik & 35 & 23,3 \\
Kader/Şanssızlık & 18 & 12 \\
Kadın Olmak & 16 & 10,7 \\
Kendi Başarısızlıkları & &
\end{tabular}


Engelli Olmak

Hastal1k

Azınlık Olmak

Yoksulluk Nedeniyle

Hissettikleri Duygular

Yetersizlik

89

44

34

28

23

14

Suçluluk

Yoksulluk Nedeniyle

Yaşadıkları En Önemli

\section{Sorun}

İhtiyaçlarını

109

Karşılayamamak

Çocuklarının İhtiyacını

Karşılayamamak

Ev Sahibi Olamamak

Dikkate Alınmamak

Toplumdan Dişlanmak

Kadınların Erkeklere Göre

Yoksulluktan Etkilenme

Durumunu Değerlendirme

Evet

112

24

14

Kısmen

Hayır
8

4

2,7

59,3

29,3

22,7

18,7

15,3

9,3

72,7

38,7

18

16

$21 \quad 14$

Kadınların Yoksulluktan

Erkeklere Göre

Etkilenmesine İlişkin

Nedenler 


\section{Kadın Erkeğe}

Bağımlıdır

Çocuk ve Evin Sorumluluğu

Kadındadır

Erkekler Sorunları Kadınlar

Kadar Önemsemez

Kadınlar Erkekler Kadar

Rahat Çalışmaz
40,4

28

18

5

Yoksul bireylerin yoksulluğu kendilerine göre tanımlama biçimleri ve atıfları, program ve politika geliştiriciler için yararlı olarak görülmektedir (Çukur, 2008). Bu kapsamda araştırmaya katılan yoksul kadınlar yoksulluğu en çok ihtiyacını karşılayamamak (\%63,3), başkasına muhtaç olmak $(\% 16,8)$ ve geçinememek $(\% 9,3)$ olarak tanımlamaktadırlar. Yoksulluk, yalnızca tek bir tanıma indirgenemeyecek kadar kapsamlı bir kavramdır.

"Yoksulluk, en temel anlamıyla "yokluk" durumunu, gereksinimlerini karşllayacak temel maddi olanaklardan "yoksun” olma" (Topgül, 2013, s.279) olarak tanımlanmaktadır. Dolayısıyla, yoksul kadınların kendileri de içinde bulundukları yoksulluk durumunu yoksunluk hali üzerinden tanımlamakta oldukları görülmektedir.

Öte yandan katılımcılar yoksulluğun nedenini en çok işsizlik (\%78) ve toplumsal eşitsizlik (\%54,7) olarak belirtmektedirler. Buradan yola çıkarak, kadınların yoksulluğu daha çok ihtiyaç temelinde tanımladıkları ve genel olarak yoksul olma nedenini yapısal nedenlere bağlı olarak açıkladıkları görülmektedir. Literatürde yoksulluğun nedenleri üç başlikta ifade edilmektedir. İlki yoksulluğu bireylerin kendi sorumluluğuna atfeden kişisel nedenler, ikincisi işsizlik, adil olmayan gelir dağılımı vb. sosyo-ekonomik ve politik çerçevedeki yapısal nedenler ve kader, şans vb. kadere bağlı nedenleridir (Başbakanlık Aile ve Sosyal Araştırmalar Genel Müdürlüğü, 2010, s.50; Uluocak, Çelik ve Şahin, 2010, s.47; Furnham, 2003, s.169; Turner ve Lehning, 2007, s.70). Erdem'in (2003) yoksul bireylerle gerçekleştirdiği başka bir araştırmanın sonuçlarında da yoksul bireyler yoksul olma nedenlerini en çok yapısal nedenlerden işsizlik ile açıklamışlardır. Ekinci Hamamcı ve Anık'ın (2020) yoksul kadınlarla gerçekleştirdiği bir başka çalışmaya göre de katılımcılar yoksulluk nedenini en çok işsizlik olarak belirtmişlerdir. Bu verilerden yola çıkarak 
yoksulların yoksul olma nedenini daha çok işsizliğe bağlı gördükleri, bununla birlikte bir iş sahibi olmanın yoksulluklarını ortadan kaldıracağını düşündükleri sonucuna ulaşılabilmektedir. Başka bir değişle, yoksullar için hâlihazırda bir işte çalışıyor olmak, az da olsa düzenli bir gelir elde etmek ve temel ihtiyaçların bir nebze de olsa karşılanması anlamına gelmektedir.

Katılımcılar yoksulluk nedeniyle en çok yetersizlik $(\% 59,3)$ ve utanma $(\% 29,3)$ duygusu hissetmektedirler. Nitekim yoksulluğun bireyler üzerinde kronik anlamda yetersizlik hissi doğuracağı ifade edilmektedir (Çukur, 2008). Yoksulluk bireylerin utanç ve aşağılanma gibi duygular hissetmesine neden olmakta, özellikle kadınlar için de daha çok stres ve depresyona yol açtı̆̆ bilinmektedir (Tarkowska, 2002; Belle ve Doucet, 2003).

Yoksulluk, bireylerin başta gıda ve barınma, olmak üzere ihtiyaçlarını karşılayamamaları ile karakterize bir durumdur. Nitekim yoksul kadınlarda, yoksulluk nedeniyle yaşadıkları en önemli sorunu öncelikle kendi ihtiyaçlarını karşılayamamak $(\% 72,7)$ daha sonra çocuklarının ihtiyaçlarını karşılayamamak $(\% 38,7)$ olarak belirtmişlerdir. Katılımcıların yoksulluk tanımları ile yoksulluk nedeniyle yaşadıkları en büyük sorunu birbirine yakın bir şekilde ifade ettikleri, "ihtiyaçlarını karşılayamamak" şeklindeki vurguyu ise her iki sorudaki yanıtlarda yineledikleri görülmektedir. Yoksul kadınların yoksullukla bağlantılı diğer sorunu ise ev sahibi olamamak (\%18) şeklinde ifade etmişlerdir. Katılımcıların yoksullukla bağlantılı ihtiyaç ve barınma temelli sorunlara ek olarak yaşadıkları diğer sorunları dikkate alınmamak (\%16) ve toplumdan dışlanmak (\%14) şeklinde yanıtladıkları görülmektedir. Başka bir değişle katılımcılar yoksulluk nedeniyle toplumsal anlamda da dışlanmayı deneyimlediklerini vurgulamışlardır.

Katılımcılar, kadınların erkeklere göre yoksulluktan daha çok etkilendiğini (\%74,7) düşünmektedir. Bunun nedeni olarak ise en çok kadının erkeğe bağımlı olmasını $(\% 40,4)$ çocuk ve evin sorumluluğunun kadında olmasını (\%28) ifade etmektedirler. Başka bir değişle katılımcılar, kadınların yoksul olma nedenlerini toplumsal cinsiyet eşitsizliği bağlamında ifade etmektedirler. Nitekim yoksul kadınların düzenli bir gelire sahip olmamaları onları eşlerine bağımlı kılan en önemli unsurlardandır. Söz konusu bağımlılık durumunun ötesinde, kadınlar hane içerisinde kendilerinden beklenen ev işlerine ilişkin sorumluluk ve bakım rollerini de ifade etmektedirler. Dolayısıyla katılımcıların, kadınların yoksul olma nedenini toplmsal cinsiyet eşitsizliği temelinde tanımladıkları görülmektedir. 
Tablo 4. Yoksul Kadınların Yoksullukla Baş Etme Stratejileri ve Güç Durumları

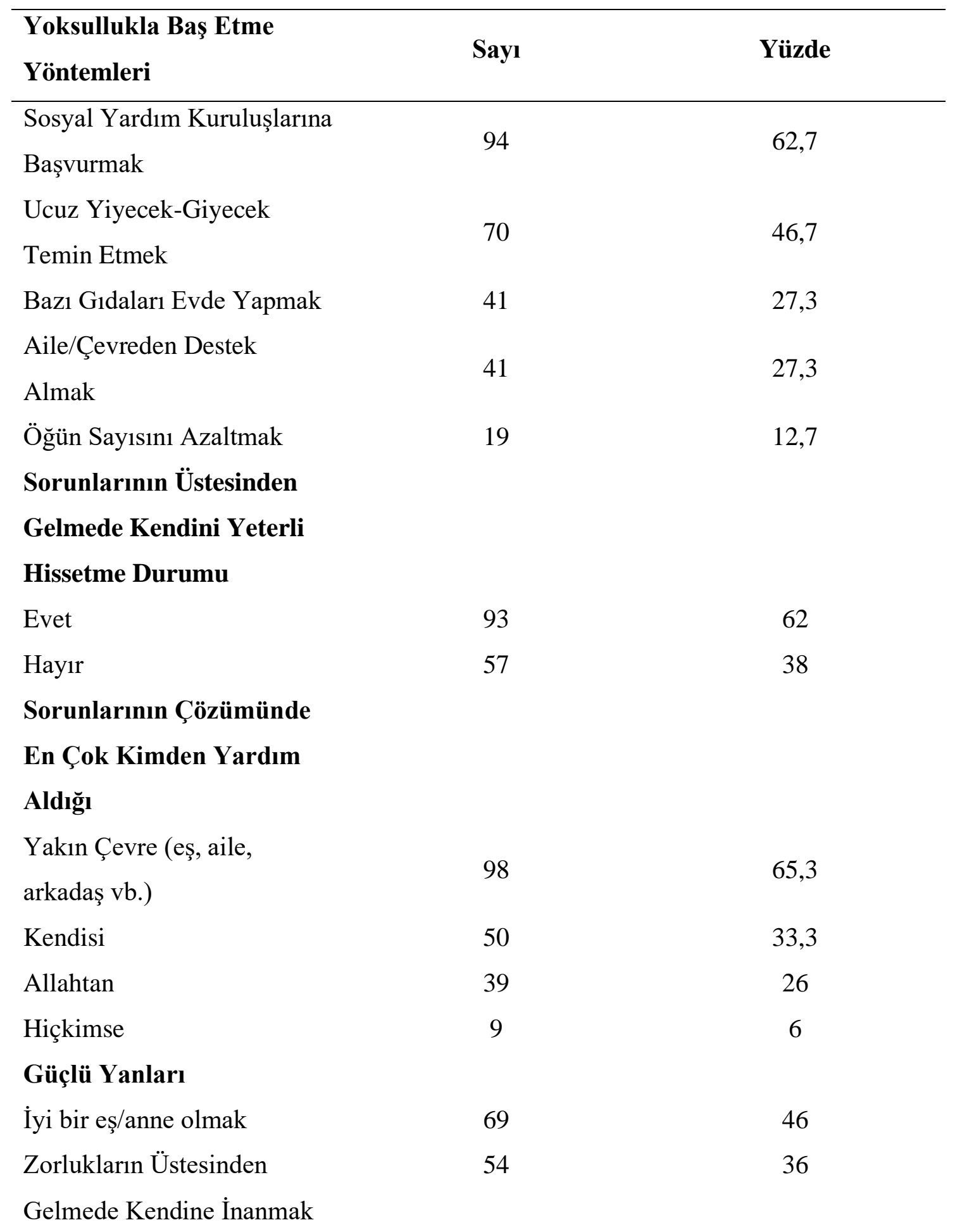


Sağlıklı Olmak

Kendini İyi İfade Edebilmek

Hayatı Üzerinde Denetim

Sahibi Olmak

Geleceğe Dair Umudu

Olmak

\section{Yaşamını Değiştirme}

Yönünde Bugüne Kadar

\section{Yaptıkları}

Çalışmak

Hiçbir şey

Diğer

Eğitimine Devam Etmek

\section{Geleceğine Yönelik}

Değerlendirmeleri

Aynı

İyi

Çok Daha Kötü

Yoksulluğun Çözümüne

\section{Yönelik Beklentileri}

Yardım Miktarı Arttırılmalı

İş İmkânı Sağlanmalı

Gerçek İhtiyaç Sahiplerine

Yardım Yapılmalı

Diğer

Yabancilar Yerine Türk

Vatandaşlara Daha Çok

Yardım Yapılmalı

Ekonomik Kriz Çözülmeli
67

58

30

9

4

42

28

34

22,7

33

22

29

19,3

36

24

13

44,7

24

16

8,7

38,7

32,7

20

6

2,7

66

44

24

16

14

9,3

11

6,7

10

6,7

8

5,3 
Yoksulların, yoksulluğu tanımlama ve anlamladırma şekillleri, onunla nasıl baş ettiklerini de işaret eden önemli değişkenlerdendir (Çukur, 2008). Yoksul ailelerde genellikle çocuk, yaşlı, engelli bakımı, hane içi üretim ve sosyal yardım başvuruları kadınlar tarafından yerine getirilmektedir. Kültürel olarak erkek, evin geçimini sağlamadan sorumludur. Kadınların böyle bir sorumluluğu bulunmadığından yoksulluğu bir anlamda "itiraf" etme konusunda daha rahat olmakta, sosyal yardımlara ulaşma, ucuz yiyecek giyecek temin etme ya da çevreden destek arama da kadınlar için daha kolay olmaktadır (Şener, 2009). Bu kapsamda katılımcıların yoksullukla baş etmelerine yönelik dağılıma bakıldığında ise en çok sosyal yardım kuruluşlarına başvurmak (\%62,7), ucuz yiyecek-giyecek temin etmek $(\% 46,7)$ ve bazı gıdaları evde yapmak $(\% 27,3)$ gibi daha çok hanenin de temel ihtiyaçlarını karşılamaya yönelik ve hane içi yeniden üretimi de işaret eden seçenekleri belirttikleri görülmektedir. Nitekim yoksullukla ilgili yaşadıkları en önemli sorunu 'ihtiyaçlarını karşılayamamak' olarak ifade eden katılımcıların, yoksullukla baş etmelerinde ihtiyaçlarını karşılamaya yönelik seçenek kapsamında yanıtlar vermesi bu anlamda anlaşılabilir görülmektedir.

Yoksul kadınların \%62'si sorunlarının üstesinden gelmede kendini yeterli hissetmektedir. Sorunların çözümünde kendine inanma ve yeterli hissetme, özünde bireylerin güçlü yanları ile ilgilidir. Bu noktada yoksul kadınların kendilerine olan bu inançları, onların güçlü yanını oluşturmaktadır. Bununla birlikte katılımcılar sorunlarını çözerken en çok yakın çevrelerini oluşturan eş, aile, arkadaşlarından $(\% 65,3)$ yardım aldıklarını ifade etmişılerdir. Bunu, kendimden $(\% 33,3)$ cevabı izlemektedir. Başka bir değişle yoksul kadınlar sorunlarla mücadele en çok yakın çevreleri ve kendilerinden destek almaktadırlar. Bilindiği üzere sosyal destek sistemleri, yoksul kadınların enformel kaynaklarından en önemlisini oluşturmaktadır. Düşük gelir, yetersiz barınma ve beslenme, damgalanma, utanç, devam eden stres durumu yoksulluk içinde yaşayan kadınların günlük sorunlarındandır. Yoksul bireylerin bahsedilen bu sorunlarla başa çıkmasında ise sosyal destek mekanizmalarının önemi gündeme gelmektedir (da Silva, de Souza Feitosa, Nepomuceno, Silva, Ximenes, Bomfim, 2019).

Katılımcıların güçlü yanlarının neler olduğuna ilişkin dağılıma bakıldığında ise en çok iyi bir eş/anne olmak (\%46) yanıtını verdikleri görülmektedir. Özünde, yoksul kadınlar toplum tarafından da genel olarak kadınlar için makbul görülen ve yerine getirilmesi takdir edilen kadınlık rollerinden anne ve eş tanımlamasını, kendileri için güçlü bir yan olarak değerlendirmektedirler. 
Bununla birlikte katılımcılar diğer güçlü yanlarını kendine inanmak (\%36) olarak belirtmişlerdir. Buradan hareketle, söz konusu katılımcıların öz yeterliliğe sahip oldukları görülebilmektedir. Ek olarak, kadınlar sağlıklı olmak (\%28), kendini iyi ifade edebilmek $(\% 22,7)$, hayatı üzerinde denetim sahibi olmak (\%22) ve geleceğe dair umudu olmak (\%19,3) olarak da güçlü yanlarını ifade etmişlerdir.

Katılımcıların yaklaşık yarısı $(\% 44,7)$ bugüne kadar yaşamını değiştirme yönünde en çok çalıştığını belirtmiştir. Bununla birlikte hiçbirşey (\%24) yapmadığını belirtenlerde bulunmaktadır. Başka bir araştırmanın sonuçlarına göre yoksul kadınların yoksulluğu iki yönden deneyimledikleri, hem yoksulluk nedeniyle acı çektikleri, hem de bu acıyla birlikte baş etmeye çalıştıklarıdır (Krumer-Nevo, 2008). Araştırma sonuçlarında da bu sonuca paralel olarak katılımcıların bir kısmının çalışarak aslında bir mücadele ortaya koyduğu, bir kısmının ise herhangi bir mücadeleye girmediği anlaşılmaktadır. Diğer (\%16) seçeneğini belirtenler ise 'Birikim yapmak, iş başvurusunda bulunmak, kendi kararını vermek, umudunu kaybetmemek' olarak ifadede bulunmuştur.

Katılımcıların geleceğe yönelik değerlendirmelerinin neler olduğuna ilişkin soruya \%38,7'si "aynı" yanıtın vermiştir. Buradan yoksul kadınların geleceğe yönelik, yaşamlarının değişmesi için bir planlarının olmadığı, var olan durumlarının süreceğine inandıkları sonucu çıkmaktadır. Yoksulluğun çözümüne yönelik beklentilerini ise aldıkları sosyal yardımların arttırılması (\%44) şeklinde açıklamışlardır. Bununla birlikte iş imkânı sağlanmalı (\%16), gerçek ihtiyaç sahiplerine yardım yapılması $(\% 9,3)$, yabancılar yerine Türk vatandaşlara yardım yapılması $(\% 6,7)$, ekonomik krizin çözülmesi $(\% 5,3)$ ve diğer seçeneği olarak $(\% 6,7)$ 'Yardımlara bağımlılı̆̆ın azaltılması, asgari ücretin yükseltilmesi, ev hanımlarına asgari ücret ve emeklilik verilmesi' şeklinde düşüncelerini belirtmişlerdir. Ülkemizde gerçekleştirilen başka bir araştırmanın sonuçlarına göre de yoksul kadınların yoksulluğun giderilmesine yönelik devletin yapması gerekenleri önceleyen düşüncede oldukları tespit edilmiştir (Alptekin ve Aksan, 2010). Söz konusu araştırmanın sonuçları da bu araştırmanın sonuçları ile benzerdir. Nitekim katılımcılarda en çok devletin sorumluluğundaki sosyal yardımların arttırılması ve işsizliğin giderilmesini belirtmişlerdir. Geçimini en çok sosyal yardımlarla sağlayan ve daha önce yoksulluğun çözümü olarak işsizliğin giderilmesini ifade eden katılımcılar, yoksulluğun çözümüne yönelik benzer konularda cevaplar verdikleri görülmektedir. 


\section{Sonuç}

Kadın yoksulluğu ya da yoksulluğun kadınlaşması kavramı, kadınların pek çok alanda yaşamış oldukları eşitsizlikler temelinde 1970'li yıllardan bu zamana kadar tartışılan önemli sosyal sorunların başında gelmektedir. Kadın yoksulluğu ile mücadelede ise kamu tarafından sunulan hizmetlerin başında sosyal yardım programları öne çıkmaktadır.

Araştırma kapsamında sosyal yardım programlarından yararlanan yoksul kadınların, daha çok genç yaş grubunda, düşük eğitim düzeyine sahip, görücü usulü ile küçük yaşlarda evlilik gerçekleştirmiş̧, en çok üç çocuğa sahip oldukları görülmektedir. Her ne kadar kadınlar için eğitimli olmak yoksul olmamak anlamına gelmese de, eğitim düzeyinin yüksek olması, kadınların daha düzenli ve gelir getiren işlerde çalışmasını kolaylaştıran bir değişkendir. Bununla birlikte, erken yaşta evlenmek kadınları yoksulluk anlamında daha riskli duruma getirmektedir. Erken yaşta evlenen kadınlar, eğitim yaşamından uzaklaşmakta, ekonomik anlamda da erkeğe bağımlı hale gelmektedir. Bu nedenle, kız çocuklarının eğitimine devam etmesi ve erken yaşta evliliklerle mücadele, sosyal politikalar açısından önemli bir yerde durmaktadır.

Katılımcıların büyük bir kısmının düzenli ve gelir getirici işlerde çalışmadıkları, bunun en büyük nedeni olarak ise çocuk bakımı ve eşin izin vermemesi olarak açıklamada bulundukları görülmektedir. Başka bir değiş̧le kadınlar, güçlenmeleri ve içinde bulundukları yoksulluktan kurtulmada önemli bir değişken olan çalışma hayatına katılımı annelik rolü gereği ya da ataerkil zihniyete dayalı nedenlerle gerçekleştirememektedirler. Öte yandan, yoksul kadınlar kamudan aldıkları sosyal yardımları her ne kadar yeterli bulmasalarda bir geçim aracı olarak görmektedirler. $\mathrm{Bu}$ noktada sosyal yardımların bireyleri kendilerine yeterli hale gelmelerinde bir araç olarak ele alan yaklaşımın, burada işlevsel olmadığı sonucu çıkmaktadır. Ülkemizde sunulan sosyal yardımların miktar olarak düşük olduğu, yoksulların temel ihtiyaçlarını karşılamalarında yeterli olmadığı bilinmektedir. Dolayısıyla, söz konusu yardım programlarının yeniden yapılandırılmasına ihtiyaç duyulduğu değerlendirilmektedir.

Bununla birlikte, yoksul kadınlar özelinde daha çok politika ve program geliştirilmesi, geliştirilecek her bir faaliyete ilişkin etki analizlerinin yapılarak, daha nitelikli hizmetlerin 
oluşturulması gerektiği değerlendirilmektedir. Araştırma sonuçlarından da görüleceği üzere, sosyal yardım programları yoksul kadınların güçlenmeleri ve kendilerine yeterli hale gelmelerinde tek başına yeterli olmamaktadır.

\section{Kaynakça}

ACA, Z., ÖZDEMIR, M.Ç., ve ALPER, Y., 2018. "Kamusal Sosyal Yardımların Yapabilirlik Yaklaşımı Çerçevesinde Etkinliği Analizi: Bursa Örneği". Yönetim ve Çalışma Dergisi. 2(2), ss. 93-117.

ALPTEKIN, D. ve AKSAN, G., 2010. "Yoksulluk ve kadın: Teorik ve Uygulamalı Bir Çalışma" Yayına hazırlayan Mahmut KARDAŞ, Uluslararası Yoksullukla Mücadele Stratejileri Sempozyumu Deneyimler ve Yeni Fikirler, İstanbul: T.C. Başbakanlık Sosyal Yardımlaşma Ve Dayanışma Genel Müdürlüğü, ss. 421-434.

APAYDIN, A., 2011. "Social Assistance as a Poverty Alleviation Strategy: Case of Altındağ Social Assistance and Solidarity Foundation". ODTÜ Sosyal Bilimler Enstitüsü, Yayınlanmış Yüksek Lisans Tezi, Ankara.

Başbakanlık Aile ve Sosyal Araştırmalar Genel Müdürlüğü., 2010. "Sosyal Yardım Algısı ve Yoksulluk Kültürü Türkiye'de Kamusal Sosyal Yardım Alanların Yardım Algısı ve Yoksulluk Kültürü Araştırması. " Yayın No:144. Ankara.

BELLE, D. ve DOUCET, J., 2003. "Poverty, Inequality and Discrimination as Sources of Depression among U.S. Women". Psychology of Women Quarterly. (27), ss.101-113.

BUĞRA, A. ve KEYDER, Ç., 2007. "Sosyal Yardım Uygulamaları ve Topluma Yararlı Faaliyet Karşılığında Asgari Gelir Desteği Uygulaması”, Birleşmiş Milletler Kalkınma Programı (BM\&UNDP) için Hazırlanan Rapor, Ankara Erişim Tarihi:05.06.2021. https://www.undp.org/content/dam/turkey/docs/Publications/PovRed/socialassista ncereports. pdf.

BUĞRA, A. ve Keyder, Ç., 2002. "Bir Temel Hak Olarak Vatandaşlık Gelirine Doğru". İstanbul: İletişim Yayınları. 
ÇAMUR DUYAN, G., 2010. "Yoksulluğun Kadınlaşmasi: Altındağ Örneği", Aile ve Toplum Dergisi. (11)6, ss. 19-29.

ÇUKUR, C. Ş., 2008. "Yoksulluğun Psikolojisi: Yoksulluğun Sosyal Bilişsel Olarak Yapılandırılması ve Sosyal-Duygusal Sorunlar ile Ilişkisi", içinde: Türkiye'de Yoksulluk Çalı̧̧maları (Editör: A. Duru Salıcı), Yakın Kitabevi Yayınları, İzmir,. ss. 97-154.

da SILVA, L.B., de SOUZA FEITOSA, M.Z., NEPOMUCENO, B.B., SILVA, A.M.S., XIMENES, V.M., BOMFIM, Z.Á.C., 2019. "Social Support as a Way of Coping with Poverty". İçinde. Ximenes V., Moura Jr. J., Cidade E., Nepomuceno B. (editör) Psychosocial Implications of Poverty. Springer, Cham. https://doi.org/10.1007/978-3-030-24292-3_9.

EAST, J. F. ve ROLL, S., 2015. "Women, Poverty and Trauma: An Empowerment Practice Approach", Social Work. (60) 4, ss. 279-286. DOI: 10.1093/sw/swv030

ECEVIT, Y., 2003. "Toplumsal Cinsiyetle Yoksulluk İlişsisi Nasıl Kurulabilir? Bu İlişki Nasıl Çalışılabilir?", Cumhuriyet Üniversites, Tıp Fakültesi Dergisi. (25) 4, ss. 83-88.

EKİNCİ HAMAMCI, E.D. ve ANIK, K., 2020. "Kadınların Yoksullukla Mücadelesinde Sosyal Yardımların Rolü: Erzurum'da Bir Uygulama". ETÜ Sosyal Bilimler Enstitüsü Dergisi (10), ss.105-131. HTTP://DX.DOİ.ORG/10.29157/ETUSBE.134.

ERDEM, T., 2003. "Yoksulluk Kimin Sorunudur?" Ekonomik Yaklaşım. 14 (49), ss. 130-149. http://www.ekonomikyaklasim.org/fulltext/94-1395759052.pdf.

FURNHAM, A., 2003. "Poverty and Wealth". CARR S.S. ve SLOAN T.S. (Ed.) Poverty and Psychology From Global Perspective to Local Practice. (ss. 163- 183). New York: Springer Science Business Media.

KALAYCIOĞLU, S. ve RITTERSBERGER-TILIÇ, H., 2002. "Yapısal Uyum Programlarıyla Ortaya Çıkan Yoksullukla Başetme Stratejileri". A. Alpay Dikmen (Ed.), Kentleşme, Göç ve Yoksulluk (ss. 197-246). Ankara: İmaj Yayınc1lı.

KARATAŞ, K., 2002. "Yoksullukla Mücadelede Bir Sosyal Politika Aracı Olarak Sosyal Yardımlar.", Türkiye İnsan Hakları Hareketi Konferansı, 15-17 Kasım 2002, Türkiye İnsan Hakları Yayınları (32), Ankara. 
KARDAM F. ve YÜKSEL İ., 2004. "Kadınların Yoksulluğu Yaşama Biçimleri: Yapabilirlik ve Yapabilirlikten Yoksunluk". Nüfusbilim Dergisi 26(1), ss. 45-72.

https://dergipark.org.tr/tr/pub/nufusbilim/issue/22964/245731 (06.06.2021).

KRUMER-NEVO, M., 2008. "From Noise to Voice How Social Work Can Benefit from the Knowledge of People Living in Poverty", International Social Work. (51)4, ss. 556-565.

OTOO-OYORTEY N. ve POBİ S., 2003. "Early marriage and poverty: Exploring links and key policy issues." Gender and Development 11(2): 42-51. http://www.jstor.org/stable/4030639.

RAO GUPTA, G., 2012. "Women and Poverty", Global Women’s Issues Women in The World Today. United States Department Of State Bureau Of International Information Programs. https://publications.america.gov/wp content/uploads/sites/8/2016/05/Global-WomensIssues_Women-in-the-World Today_English_508.pdf (29.05.2021).

ŞENER Ü., 2009. "Kadın Yoksulluğu". Türkiye Ekonomi Politikaları Araştırma Vakfı Değerlendirme Notu.

https://www.tepav.org.tr/upload/files/1271312994r5658.Kadin_Yoksullugu.pdf. (01.05.2021)

TARKOWSKA, E., 2002. "Intra-Household Gender Inequality: Hidden Dimensions of Poverty Among Polish Women". Communist and Post-Communist Studies. (35), ss. 411-432.

TURNER K. ve LEHNING A., 2007. "Psychological Theories of Poverty", Journal of Human Behavior in the Social Environment. (16)1-2, ss.57-72.

TOPGÜL S., 2013. "Türkiye'de Yoksulluk ve Yoksulluğun Kadınlaşması", Cumhuriyet Üniversitesi İktisadi ve İdari Bilimler Dergisi, 14(1), ss.277-296. https://www.acarindex.com/dosyalar/makale/acarindex-1423875011.pdf. Erişim Tarihi: 12.06.2021.

ULUOCAK, P.G., ÇELİK, G. ve ŞAHİN, F., 2010. "Sosyal Yardımlaşma ve Dayanışma Vakfı Personelinin Yoksulluğun Nedenlerine İlişkin Algılamalarını Belirlemek". Uluslararası Yoksullukla Mücadele Stratejileri Sempozyumu: Deneyimler ve Yeni Fikirler Bildiriler Kitabı 1315 Ekim İstanbul.

TÜİK, [Türkiye İstatistik Kurumu] 2021, Mart İstatistiklerle Kadın 2020. Haber Bülteni Say1: 37221. https://tuikweb.tuik.gov.tr/PreTablo.do?alt_id=1068. (16.05.2021). 
Journal of Social Research and Behavioral Sciences, Volume: 7 Issue: 13 Year: 2021

TÜiK, 2020, Eylül. Gelir ve Yaşam Koşulları Araştırması, 2019. Haber Bülteni Sayı: 33820. https://tuikweb.tuik.gov.tr/PreTablo.do?alt_id=1068\#. (17.05.2021).

ÜNLÜTÜRK ULUTAŞ, Ç., 2009. "Yoksulluğun Kadınlaşması ve Görünmeyen Emek", Çalışma ve Toplum Dergisi. 2(21): ss.25-40. 